\title{
Sporadic high abundances of naked amoebae in Black Sea plankton
}

\author{
Sergey A. Murzovi, David A. Caron ${ }^{2, *}$ \\ ${ }^{1}$ Institute of Biology of the Southern Seas, Ukrainian Academy of Sciences, 2 Nakhimov Ave., Sevastopol 335011, Crimea, \\ Ukraine \\ ${ }^{2}$ Biology Department, Woods Hole Oceanographic Institution, Woods Hole, Massachusetts 02543, USA
}

\begin{abstract}
The abundance of non-testate ('naked'), free-living amoebae was examined in surface waters of the Black Sea during 5 cruises in 1992 and 1993 . Amoebae $(\leq 20 \mu \mathrm{m}$ in size $)$ were observed in samples collected during 2 of the 5 cruises at abundances up to approximately $380 \mathrm{ml}^{-1}$ The abundance and biomass of amoebae were low relative to other nanoplanktonic protozoa when averaged over all stations, but amoebae occasionally constituted a major component of the heterotrophic nanoplanktonic assemblage (up to $16 \%$ of abundance and $93 \%$ of biomass of the protozoa 2 to $20 \mu \mathrm{m}$ in size). Abundances of amoebae correlated weakly with the total number of heterotrophic nanoplankton, and with ash free dry weight, but not with several other physical, chemical and biological parameters. Based on the highest abundances of naked amoebae observed in this study we suggest that these protozoa can occasionally be important in energy and elemental cycling in Black Sea plankton.
\end{abstract}

KEY WORDS: Amoebae Protozoa Plankton

\section{INTRODUCTION}

Recent synopses of research on the 'microbial loop' (sensu latu Pomeroy 1974, Azam et al. 1983) indicate that there is a growing consensus among ecologists on many of the major features of aquatic microbial food webs (Hobbie 1994). In particular, major roles have been firmly established for flagellated and ciliated protozoa (Sherr \& Sherr 1994). Nevertheless, there are still a number of aspects of protozoan assemblages and their interactions which remain enigmatic. The importance of free-living, non-testate amoebae (the 'naked' amoebae) in the energetics of aquatic communities is clearly one of these features. The benchmark monograph of Schaeffer (1926) established the presence of a diverse fauna of amoebae in aquatic ecosystems. Since that study, however, there has been much less information acquired on the abundances and interactions of this assemblage in aquatic food webs than for other components of protozoan communities.

\footnotetext{
-Addressee for reprint requests. E-mail: dcaron@whoi.edu
}

There is a general acceptance that amoebae play a significant role in nutrient cycling within soil ecosystems (Alexander 1961). There is also a perception that they are of minor importance in most aquatic environments (particularly in the plankton) where flagellates and ciliates dominate the biomass and activities of protozoan assemblages (Fenchel 1987, Capriulo 1990, Reid et al. 1991). While this perception may be true on average, our knowledge of the ecology of free-living amoebae is still too rudimentary to place firm limits on the degree to which they contribute to living biomass or affect energy transfer in planktonic ecosystems.

Difficulties associated with counting and identifying amoebae in nature hinder our understanding of their ecology. Species diversity of the non-testate amoebae is still relatively poorly characterized because identifications are based in part on features of the living cells. In addition, the trophic activities of many of the species are inadequately defined, making it difficult to estimate the contribution of amoebae to energy and elemental flow in natural aquatic communities. Given these limitations, it is not surprising that much of the interest in free-living amoebae has been limited to 
potential human pathogens (Sawyer et al. 1977, 1993. Daggett et al. 1982, Kyle \& Noblet 1985, Sawyer 1989).

Amoebae are widely distributed in both freshwater and marine plankton communities, although there are few quantitative data on their occurrence in natural waters. They have been documented from a diverse array of freshwater habitats, and their ecology in those ecosystems has been reviewed recently (Cook et al. 1974, O'Dell 1979, Kyle \& Noblet 1986, 1987, Laybourn-Parry et al. 1991. Arndt 1993). Abundances of free-living non-testate amoebae reported from freshwater planktonic communities have ranged from $<0.1 \mathrm{ml}^{-1}$ up to several hundred $\mathrm{ml}^{-1}$ based on the use of Most Probable Number (MPN) cultural methods to estimate abundance. On average, these numbers are modest relative to the densities of heterotrophic nanoflagellates in fresh water (Berninger et al. 1991), but most nanoflagellate abundances typically have been obtained using direct counting methods and epifluorescence microscopy (Sherr et al. 1993). Interestingly, cultural estimates of the abundances of heterotrophic nanoflagellates are typically 1 to 2 orders of magnitude less than the abundances of heterotrophic nanoflagellates obtained using direct counting methods, but similar to the abundances of amoebae determined by MPN culture methods (Caron et al. 1989). Based on this type of reasoning, Arndt (1993) has concluded that the importance of naked amoebae, particularly small species, has been underestimated in lake ecosystems up to the present time.

The contribution of non-testate amoebae to marine plankton generally has been overshadowed by the importance of the more conspicuous sarcodine taxa within the Acantharea, Foraminiferida, Polycystinea and Phaeodarea (Caron \& Swanberg 1990). Nevertheless, amoebae have been observed from a wide range of marine environments, including estuaries, coastal and open ocean pelagic ecosystems, and shallow and deep ocean sediments (Bovee 1956, Lighthart 1969. Sawyer 1971, 1975a, b, 1980, Davis 1976, Sieburth et a]. 1976, Anderson 1977, 1994, Sawyer et al. 1977. 1993, Davis et al. 1978, Burnett 1981, Caron et al. 1982, 1986, Fernandez et al. 1989, Rogerson 1991. Alongi 1992, Rogerson \& Laybourn-Parry 1992, Vørs 1993a, b, Butler \& Rogerson 1995). Abundances of culturable species of amoebae in marine plankton communities have ranged from undetectable to nearly $200 \mathrm{ml}^{-1}$, but abundances of $1-10 \mathrm{ml}^{-1}$ in estuarine/coastal waters to $1-10 \mathrm{l}^{-1}$ in oceanic waters have been more typical (Davis 1976, Davis et al. 1978, Rogerson \& LaybournParry 1992).

Free-living amoebae from both freshwater and marine planktonic environments generally are assumed to be associated with surfaces. Highest abundances in the water column have been observed at the air/water interface (Davis 1976, Sieburth et al. 1976, Davis et al. 1978, Kyle \& Noblet 1987), on the surfaces of microalgae or macroalgae (Cook et al. 1974, Anderson 1977. Kyle \& Noblet 1985, Rogerson 1991), or on suspended detrital aggregates (Caron et al. 1982, 1986, Laybourn-Parry et al. 1991, Rogerson \& LaybournParry 1992, Arndt 1993). These surfaces presumably provide both substrata for amoeboid locomotion as well as foci for microaggregations of attached bacteria and other prey organisms. Amoeba abundances up to several thousand-fold greater than in an equivalent volume of water have been demonstrated on suspended detrital aggregates and at the air/water interface. Thus, the distribution of particulate material in the plankton appears to be a major determinant in the occurrence and distribution of free-living amoebae in the plankton.

In this manuscript we report the occurrence of occasionally high abundances of naked amoebae in plankton samples collected in the Black Sea during 1992 and 1993. Most samples had undetectable or low abundances of amoebae $\left(<0.5 \mathrm{ml}^{-1}\right)$, but several samples contained abundances up to several hundred $\mathrm{ml}^{-1}$. These results confirm previous reports of amoebae in this ecosystem (Kopylov \& Sazhin 1988, 1989), and indicate a close association of amoebae with particulate material. Amoebae constituted a potentially important, although highly patchy, component of the heterotrophic nanoplankton assemblages of this environment.

\section{METHODS}

Samples were collected during 5 cruises at stations in the northern and eastern portions of the Black Sea in May, July and September 1992 and February and October 1993 (Fig. 1A). Up to 11 depths were examined at each station. All water samples were collected with $30 \mathrm{l}$ Niskin bottles. Hydrographic information (salinity, temperature, oxygen and $\mathrm{pH}$ ) was obtained from the surface to the bottom at all stations. Samples for ash free dry weight were collected on Sartorius ${ }^{\circledR}$ filters $(0.3 \mu \mathrm{m}$ pore size). Filters were weighed prior to filtration of the samples. Samples were then collected on the filters, rinsed and combusted at $500^{\circ} \mathrm{C}$ for $1 \mathrm{~h}$ prior to reweighing the filters.

Microbial abundances and biomasses were determined from light microscopical observations. Phytoplankton abundance and taxonomic composition (except phototrophic nanoplankton; see below) were determined by light microscopy using an Amplival ${ }^{\circledR}$ microscope. Phytoplankton biomass (wet weight) was calculated from abundances and biovolume estimates determined from the measurement of phytoplankton 

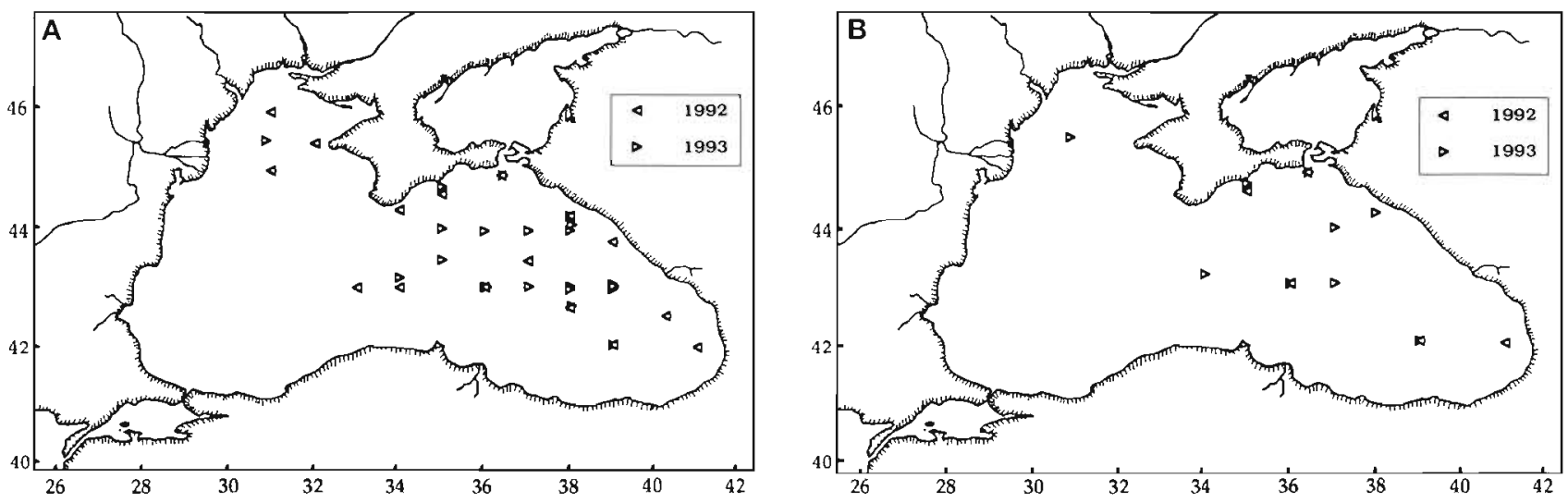

Fig. 1. Locations of (A) stations sampled for amoebae in the Black Sea during May 1992 and October 1993, and (B) stations at which amoebae were observed during the 2 cruises

cells and assuming specific geometric shapes (Makarova \& Pishkilyi 1970, Senichkina 1986a, b). Biovolume of phytoplankton was converted to biomass assuming a specific gravity of 1.0 . Phototrophic and heterotrophic nanoplankton abundances (2 to $20 \mu \mathrm{m}$ algae and protozoa, respectively) were determined from glutaraldehyde-preserved $(1 \%$ final concentration) samples by epifluorescence microscopy using the primulin technique (Caron 1983). Biomass (wet weight) of the nanoplanktonic assemblages was determined from abundance estimates and volume estimates based on the measurement of cell dimensions, and assuming a specific gravity of 1.0. Estimates of the biovolume of amoebae were exceedingly difficult because of the irregular shape and variable thickness of the cells. Estimations of amoeba biovolumes were obtained using measurements of the outline of the cells and thickness determined using a calibrated scale on the focusing knob of the microscope. Bacterial abundances were obtained for some samples using the acridine orange method (Hobbie et al. 1977).

Amoeboid cells (irregularly shaped eukaryotic cells with clear unbroken margins, radiating or eruptive pseudopodia, and clearly distinguishable nuclei) were observed in preserved samples prepared and examined for nanoplanktonic protists using epifluorescence microscopy. Cells that did not display these features were not counted as amoebae. Identification of nanoplanktonic cells as non-testate amoebae was confirmed by light microscopy on natural, live material and on enriched samples to insure that the cells being enumerated by this method were amoebae.

Direct epifluorescence microscopy of amoebae is not normally employed for enumerating these protozoa in natural samples because of the difficulties of distinguishing the cells from non-living material. Cultural estimates (MPN) are commonly used but were not possible in this study. Nevertheless, amoebae were clearly visible in some of the preparations for epifluorescence microscopy and, where present, they were enumerated along with the nanoflagellates.

We attempted to estimate the efficacy of our direct counting method for determining the abundance of naked amoebae by performing a laboratory experiment comparing direct microscopical counts and cultural (MPN) counts for a cultured amoeba (Flabellula hoguae; American Type Culture Collection \#30733). Amoebae were grown in liquid medium (natural, autoclaved seawater) on bacteria enriched with $0.01 \%$ yeast extract broth and a sterile rice grain. Samples were collected from the culture during exponential growth of the amoeba and processed in parallel for epifluorescence microscopical counts using the technique employed for nanoplankton samples in the field study and by the MPN technique. Samples for MPN cultural counts were diluted in a 2 -fold serial dilution series using filter-sterilized culture water. Four replicates of each dilution were cultured in 96-well tissue culture dishes using yeast extract broth to enrich the bacterial assemblage. Replicate plates were analyzed and the results combined to obtain an average MPN of amoebae in the original samples and to estimate the error. Direct counts by epifluorescence microscopy of F. hoguae in this analysis averaged $128 \%$ of the MPN counts, but no significant differences were observed owing to the large variability associated with the MPN estimates (average coefficient of variation $=38 \%$ ). Based on this analysis, we concluded that, for easily recognizable forms, the direct counting method provided estimates of amoeba abundances that were comparable to the MPN method.

The efficacy of the direct counting method applied to field samples, however, is difficult to assess. The estimated limit of detection for the direct counting method used here was approximately 0.5 amoebae $\mathrm{ml}^{-1}$ based on the amount of water filtered (up to $12 \mathrm{ml}$ ) and the 
portion of the filter examined $(\sim 30 \%$ of the filter area covered by sample). Therefore, amoebae may have been present in the samples at abundances $<0.5 \mathrm{ml}^{-1}$ but were undetectable by this method. This estimate also assumed that all amoebae present in the samples could be identified as amoebae. We speculate that the direct counting method may have severely underestimated the abundances of amoebae $<10 \mu \mathrm{m}$ in size which can be important in natural samples (Butler \& Rogerson 1995). Some of these individuals probably were not distinguishable from detrital material because of the non-specific staining of some detrital particles with which the amoebae were often associated. Also, some amoebae retract pseudopodia and become somewhat rounded when preserved. This behavior cuuld nake them difficuit to identify as amoebae in epifluorescence preparations. Therefore, the abundances reported here must be considered lower limit estimates of the actual abundances and biomasses of non-testate amoebae in the samples. It was not possible to conduct comparisons between the direct counting and cultural methods during the field study.

\section{RESULTS}

The occurrence of naked amoebae during this study was highly sporadic. Estimates of abundances of amoebae ranged from undetectable up to $380 \mathrm{ml}^{-1}$. Amoebae were present in samples collected at 5 stations during May 1992 and at 9 stations during October 1993 (Fig. 1B). Abundances in these samples were not restricted to stations with shallow water depths, but highest abundances were observed in samples collected near Kerch Strait with a water depth of only $42 \mathrm{~m}$. Amoebae were distinguishable in $28 \%$ of a total of 78 samples examined during the May 1992 cruise, and $13 \%$ of 116 samples examined during the October 1993 cruise. Averaged over all samples, amoebae constituted less than a few percent of heterotrophic nanoplankton (HNAN) abundance or biomass. However, amoebae contributed significantly to HNAN abundance and biomass at particular stations and depths (see below). Amoebae were not observed in any of the samples collected during the July 1992, September 1992 or February 1993 cruises. As described above, the estimated limit of detection for the counting method used here was approximately 0.5 amoebae $\mathrm{ml}^{-1}$.

Two distinct morphotypes of amoebae were observed in the preserved samples. Both morphotypes were in the nanoplankton size range $(\leq 20 \mu \mathrm{m})$. The first was 5 to $9 \mu \mathrm{m}$ in size and possessed pseudopodia up to $15 \mu \mathrm{m}$ in length in the floating stage. Specimens of this morphotype were not observed with ingested phytoplankton, and were presumably feeding on bacteria in the water and in the cultures. Biovolumes estimated for this amoeboid form ranged up to approximately $300 \mu \mathrm{m}^{3}$. This morphotype was observed at both shallow water and deep water stations in May 1992 and October 1993, with highest abundances (9.6 $\mathrm{ml}^{-1}$ ) observed near the center of the eastern divergence at a depth of $25 \mathrm{~m}$. At this depth and time, these amoebae constituted $8 \%$ of the total abundance of HNAN. Biomass calculated from these measurements indicated that amoebae constituted approximately $16 \%$ of the total biomass of HNAN in the sample with maximal abundance of amoebae. Amoebae constituted a greater percentage of HNAN biomass than of HNAN abundance because of the larger average biovolume of amoebae relative to other nannplanktonic protists. This calculation of the contribution of amoeba biomass to HNAN biomass is based on our assumption of a single biovolume:biomass conversion factor for all protists. This assumption is questionable given the differential effects of preservation on cell shrinkage and the inherently different carbon contents of some protists (Verity et al. 1992, Stoecker et al. 1994). Therefore, this value can be considered only a first-order approximation of the contribution of amoebae to HNAN biomass

The second amoeba morphotype was larger (12 to $20 \mu \mathrm{m}$ ) with short pseudopodia. Biovolumes estimated for these amoebae ranged up to approximately $900 \mathrm{\mu m}^{3}$. This morphotype was observed only during May 1992, and was observed at abundances of $<1$ amoeba $\mathrm{ml}^{-1}$ to approximately $20 \mathrm{ml}^{-1}$ in samples collected near the central eastern basin of the Black Sea (Fig. 2A). These amoebae reached highest abundances, however, at shallow water stations located near the entrance to Kerch Strait (Fig. 3A). Abundances of approximately $380 \mathrm{ml}^{-1}$ were observed in water collected at $35 \mathrm{~m}$ at the latter station. This value is among the highest abundance values reported for free-living, naked amoebae from plankton communities, and is comparable to abundances observed on some suspended macroscopic detrital aggregates (Caron et al. 1982, 1986, Arndt 1993).

The highest abundances of this second amoeba morphotype corresponded to a maximum of $16 \%$ of the total abundance of HNAN and up to $93 \%$ of the total biomass of HNAN. Integrated over the $42 \mathrm{~m}$ water column at this station, amoebae constituted $9 \%$ of the total abundance of HNAN and $79 \%$ of the HNAN biomass. The large contribution of these amoebae to HNAN biomass at this station was due to the large biovolume of this morphotype relative to other HNAN. High concentrations of particulate organic carbon, primarily algal fragments based on microscopical examination, were present in surface water samples at this station 

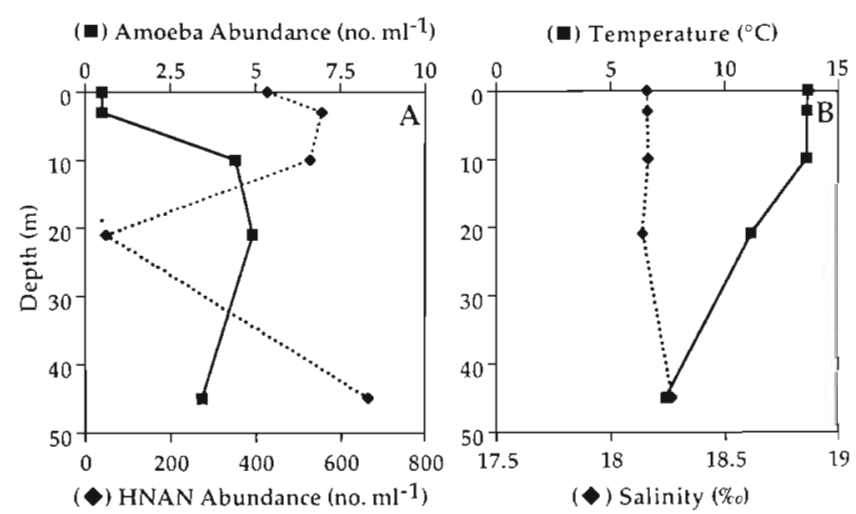

(匹) HNAN Biomass ( $\mathrm{mg} \mathrm{m}^{-3}$ )
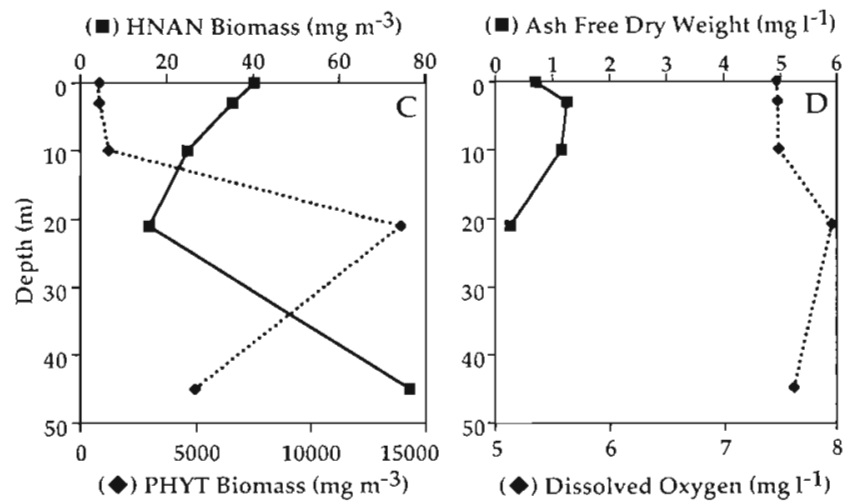

Fig. 2. Vertical profiles of (A) amoeba abundances and total heterotrophic nanoplankton (HNAN) abundances, (B) temperature and salinity; (C) total biomass of HNAN and phytoplankton (PHYT); and (D) ash free dry weight and dissolved oxygen concentration, conducted on 11 May 1992 at a station at $42^{\circ} 30^{\prime} \mathrm{N}, 39^{\circ} 00^{\prime} \mathrm{E}$ (water column depth $=2010 \mathrm{~m}$ ). 'Abundance of HNAN in this sample was probably underestimated due to poor quality of filter preparations

(Fig. 3D). Fragments of algae, whole algal cells and amorphous detrital material were observed within the vacuoles of these amoebae. The abundances of this amoeba morphotype decreased with distance from Kerch Strait, and this form was not observed in waters from the northwestern shelf area of the Black Sea.

Correlations of abundances of amoebae with chemical, physical and biological parameters measured during the study were examined for those samples that contained amoebae. No significant correlations were obtained between the abundance of amoebae and temperature, oxygen, salinity, phytoplankton abundance or phytoplankton biomass. However, the highest abundances of amoebae were observed in those samples that contained the highest abundances of phytoplankton. Amoeba numbers also were not clearly correlated with the sampling depth (Fig. 4A) or with the depth of the water column at the sampling sites (Fig. 4B). Highest amoeba abundances, however, were observed at the stations with the shallowest water columns.
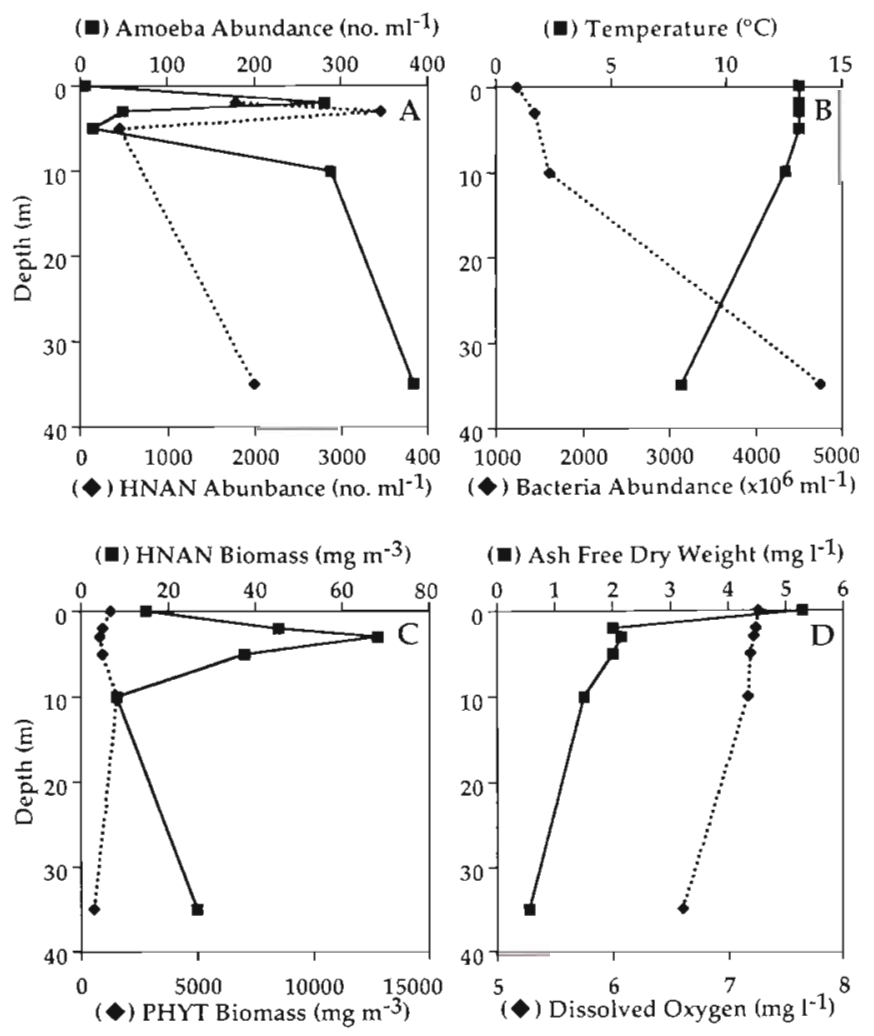

Fig. 3. Vertical profiles of (A) amoebae abundances and total HNAN abundances; (B) temperature and bacterial abundances; (C) total biomass of HNAN and phytoplankton (PHYT); and (D) ash free dry weight and dissolved oxygen concentration, conducted on 16 May 1992 at a station at $44^{\circ} 57^{\prime} \mathrm{N}, 36^{\circ} 24^{\prime} \mathrm{E}$ (water column depth $=42 \mathrm{~m}$ )

Positive, albeit weak correlations of abundances of amoebae were observed with HNAN abundances (Fig. 4C). A correlation coefficient of 0.60 was obtained for the regression of $\log$ (HNAN abundance) versus log(amoebae abundance) with 1 anomalously high data point excluded. Exclusion of the amoeba abundances from the HNAN data set did not greatly affect this relationship (correlation coefficient $=0.66$ ). Similarly, amoebae abundances correlated weakly with ash free dry weight for a somewhat smaller subset of the data (correlation coefficient $=0.64$ with 2 anomalously high values excluded). Ash free dry weight and bacterial abundance were not available for all stations and depths.

\section{DISCUSSION}

Previous studies of the HNAN of the Black Sea have emphasized the dominance of this assemblage by zooflagellate species (Kopylov \& Moiseyev 1983, Kopylov \& Sazhin 1989). However, naked, free-living amoebae have occasionally been observed in the plankton of 

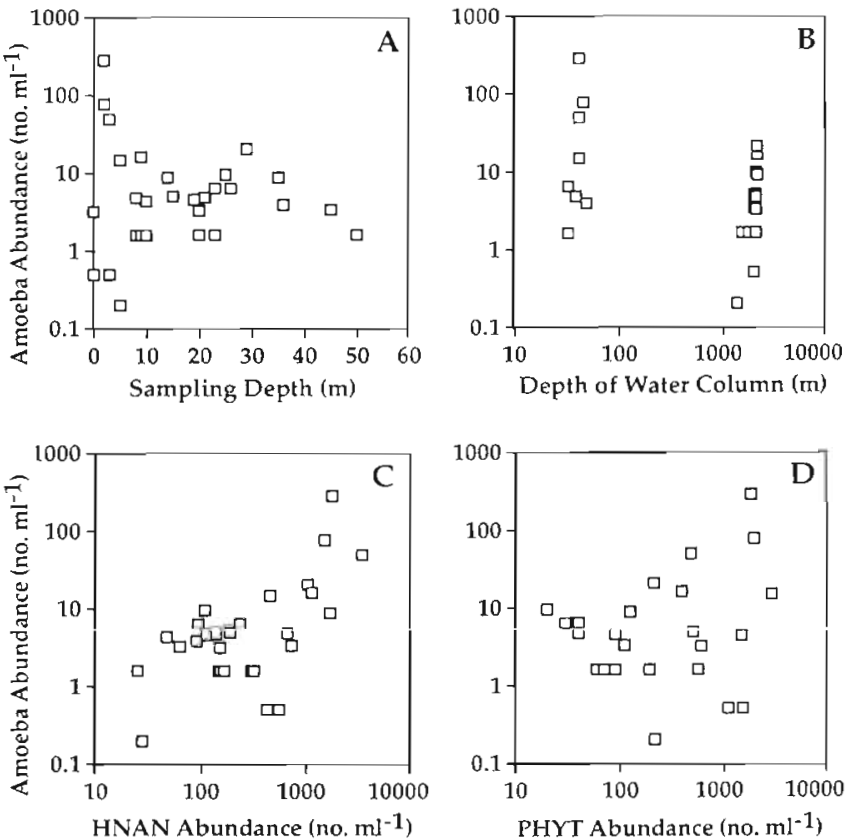

Fig. 4. Relationships between the abundance of amoebae and several biological and physical parameters for those samples in which amoebae were observed during cruises conducted in May 1992 and October 1993. (A) Depth at which each sample was collected; (B) depth of the water column at the sampling site (note: this does not specify the sampling depth); (C) total HNAN abundance including amoebae; (D) ash free dry weight

the Black Sea. Kopylov \& Sazhin (1989) noted that amoebae occasionally constituted an important component of the biomass of HNAN. Amoebae in that study Constituted up to $80 \%$ of the biomass of HNAN during May and June. No species descriptions were presented. Amoeboid cells have also been observed in coastal waters off Bulgaria (Kopylov et al. 1991) and in the sediments of this area (Valkanov 1970). These observations, together with the results presented here, indicate that amoebae are probably a common component of the plankton of this inland sea, and that they can occasionally dominate the heterotrophic species within the nanoplanktonic size class. Dominance of other marine nanoplanktonic protozoan assemblages by naked amoebae has not been reported, although such situations apparently are not uncommon in the benthos (Mare 1942, Butler \& Rogerson 1995).

Correlations of abundances of amoebae with physical, chemical or biological parameters in the plankton have been extremely rare because there are few quantitative data on the occurrence of these protozoa. Abundances of amoebae in this study typically showed subsurface maxima (Figs. 2 \& 3), although the surface microlayer was not examined. Kyle \& Noblet (1986) noted that vertical distributions of amoebae in a freshwater lake were somewhat higher in the region of the oxycline relative to abundances above or below that feature. Zubkov et al. (1992) has noted an abundant and unique protozoan fauna at the oxic-anoxic interface in the Black Sea, but the occurrence of naked amoebae apparently was not examined. The samples in this study were obtained within the oxygenated surface waters of the Black Sea, and the exact relationship between the oxycline and abundances of amoebae was not examined. High abundances of amoebae near the base of the oxygenated layer at some stations in this study may be indicative of elevated abundances associated with the oxycline (Fig. 3A), but no clear correlation was observed in regressions between abundances of amoebae and oxygen concentrations for the whole data set.

Weak conteldions were unsenved in linis siudy unly with HNAN abundances and ash free dry weight. The correlation with HNAN (composed largely of heterotrophic flagellates in most samples) was expected because of the common trophic activities of many of the flagellate and amoeba taxa. Most nanoflagellates feed phagotrophically on bacteria and small algae. Although many nanoflagellates feed on suspended microorganisms, a number of species graze microorganisms attached to surfaces (Caron 1987). Increases in the density of bacteria, and attached bacteria in particular, would be expected to result in elevated abundances of both surface-associated heterotrophic nanoflagellates and amoebae. In addition, the amoebae observed in this study were in the nanoplankton size class and thus contributed directly to HNAN abundances, albeit modestly (maximum of $16 \%$ of total HNAN abundance, usually $<10 \%$ )

We also found a weak correlation between the abundances of amoebae and ash free dry weights of suspended particulate material in this study. Microscopical examination of the fluorochrome-stained samples showed that most amoebae were attached to particles in the plankton (primarily detrital aggregates). Therefore, a correlation with ash free dry weight was not surprising. Previous studies have noted the association of naked amoebae with particulate material or other surfaces (Davis et al. 1978, Caron et al. 1986. Laybourn-Parry et al. 1991, Rogerson \& LaybournParry 1992, Arndt 1993), and mobility and feeding by most amoebae appear to be dependent on the availability of surfaces.

The weak nature of the correlation between the abundances of amoebae and ash free dry weight observed in this study is probably due to varying chemical composition and age of the particulate material sampled. The lability of the organic compounds constituting the particulate material should strongly affect the composition and extent of the microbial community accumulating and growing on suspended detrital 
aggregates. In addition, a succession of microbial species has been noted on suspended fecal material and detrital aggregates produced by marine zooplankton (Pomeroy et al. 1984, Caron et al, 1986, Davoll \& Silver 1986). Therefore, the extent of development of the microbial assemblage present on suspended detrital material at any particular time should be a consequence of the chemical composition of the detrital material and its age. In this regard, the high abundances observed during the spring and fall in this study and during the spring in the study of Kopylov \& Sazhin (1989) may indicate a relationship between amoeba abundances and the decay of the phytoplankton blooms in these regions.

Allochthonous (and transient) inputs of amoebae are also probable explanations for these protozoa in the plankton of the Black Sea in addition to growth in situ on particulate material. The highest abundances of amoebae in this study were observed near Kerch Strait. This result implicates the Sea of Azov as a significant source of amoebae for the Black Sea. Moreover, the shallow depth in this region may be indicative of the benthos as a source of suspended amoebae observed in the Black Sea near Kerch Strait during May 1992 (Fig. 3). Wind speed reached $15 \mathrm{~m} \mathrm{~s}^{-1}$ during the sampling period at that station. Resuspension of sediment material in the Sea of Azov coupled with a net flow of water into the Black Sea during the spring may be the reason for the high amoeba abundances observed at that station and time.

Amoeba abundances in the plankton near Kerch Strait were comparable to the highest abundances observed for other marine planktonic ecosystems, including estuarine ecosystems that have been examined (Davis et al. 1978, Rogerson \& Laybourn-Parry 1992). The exceptions to this generality are the high abundances that have been observed on some macroscopic detrital aggregates which constitute particularly enriched microenvironments for protozoan colonization and growth in the plankton (Caron et al. 1982, 1986). Arndt (1993) also reported abundances of naked amoebae in the plankton of Lake Müggelsee that are comparable to the highest abundances observed in the present study.

The use of epifluorescence microscopy rather than traditional MPN culture methods (Singh 1946) to estimate the abundance of amoebae may be partly responsible for the high abundances of amoebae observed in the present study. Estimates of protozoan abundance that rely on culture of the protozoa have been shown to underestimate the actual abundances of these species by up to 2 orders of magnitude (Caron et al. 1989). Interestingly, the highest abundances of amoebae observed in this study are approximately 2 orders of magnitude greater than most previous reports of amoeba abundances obtained using culture methods.
The use of a direct counting method for estimating amoeba abundances, however, also has significant drawbacks. The numbers of amoebae reported here may underestimate the actual abundances of amoebae because of the difficulties of distinguishing amoebae in preserved samples. This possibility is particularly high for very small amoebae $(<10 \mu \mathrm{m})$ which are difficult to recognize in preserved samples using epifluorescence microscopy. Thus, both MPN and direct counting techniques as they are presently used probably provide lower limit estimates of the actual number of naked amoebae present in natural samples.

Nevertheless, the abundances of naked amoebae that we observed in this study were occasionally very high relative to previous reports. Further refinements in the use of direct counting methods should considerably improve our understanding of the role of nontestate amoebae in aquatic food webs. For example, the application of oligonucleotide probes that target rRNA in eukaryotic cells may provide a means of more easily distinguishing these amorphous cells from non-living detrital material (Lim et al. 1993, 1996, Sims et al. 1994). The application of these techniques may well indicate a considerably larger ecological role for the naked amoebae than has been previously assumed.

The abundances of amoebae observed in the present study indicate a potentially important, albeit sporadic, contribution of non-testate amoebae to the microbial food web of the Black Sea plankton. Both of the dominant morphological types of amoebae observed in this study were nanoplanktonic in size (2 to $20 \mu \mathrm{m})$. Although the existence of amoebae in the marine plankton has been known for some time, only recently have microbial ecologists begun to demonstrate the ubiquitous nature of these species in freshwater and marine environments (Laybourn-Parry et al. 1991, Rogerson \& Laybourn-Parry 1992, Arndt 1993, Rogerson 1993). The abundances and potential ecological importance of these amoebae have undoubtedly been overlooked in most previous studies of protozoan ecology because of their indistinct morphologies and patchy distributions. The existence of small naked amoebae in the Black Sea plankton and other environments may indicate a rather important and poorly characterized aspect of the microbial ecology of planktonic ecosystems. Most nanoplanktonic flagellates that have been examined in culture thus far feed on suspended bacteria. There are relatively few data on species that consume attached microorganisms. Because the trophic activities of naked amoebae are largely confined to surfaces in aquatic ecosystems, these protozoa may play an important role in the dissolution and remineralization of particles and particleassociated bacteria in planktonic environments. 
Acknowledgements. The authors are grateful to the crews of the research vessels of the Ukranian Scientific Center of the Ecology of the Sea, and to Prof Dr E. Z. Samishev, Dr N. V Kovalyova, Dr S. A. Scrgin and graduate student Ju. V Bryantseva for data concerning ash free dry weights, bacterial and phytoplankton abundance and biomass. Ee Lin Lim provided technical assistance with the laboratory study comparing the direct counting and MPN methods. We also thank Elena A. Kondratyeva for translation. This work is part of the dissertation submitted by S.A.M. for the degree of Doctor of Biology.

\section{LITERATURE CITED}

Alexander M (1961) Introduction to soil microbiology. Wiley Publishing Co., New York

Alongi DM (1992) Bathymetric patterns of deep-sea benthic rommunities from bathyal to abyssal depths in the western South Pacific (Solomon and Coral Seas). Deep Sea Res $39: 549-565$

Anderson OR (1977) The fine structure of a marine ameba associated with a blue-green alga in the Sargasso Sea. J Protozool 24:370-376

Anderson OR (1994) Fine structure of the marine amoeba Vexillifera telmathalassa collected from a coastal site near Barbados with a description of salinity tolerance, feeding behavior and prey. J Eukaryot Microbiol 41:124-128

Arndt $H$ (1993) A critical review of the importance of rhizopods (naked and testate amoebae) and actinopods (heliozoa) in lake plankton. Mar Microb Food Webs 7 $3-29$

Azam F, Fenchel T, Field JG, Gray JS, Meyer-Reil LA Thingstad $F$ (1983) The ecological role of water-column microbes in the sea. Mar Ecol Prog Ser 10:257-263

Berninger UG, Caron DA, Sanders RW, Finlay BJ (1991) Heterotrophic flagellates of planktonic communities, their characteristics and methods of study. In: Patterson DJ, Larsen J (eds) The biology of free-living heterotrophic flagellates, Special Vol 45. Clarendon Press, Oxford, p 39-56

Bovee EC (1956) Observations on a marine amoeba of intertidal zones, Vexillifera telmathalassa. J Protozool 3:155-158

Burnett BR (1981) Quantitative sampling of microbiota of the deep-sea benthos. III. The bathyal San Diego Trough. Deep Sea Res 28A 649-663

Butler H, Rogerson A (1995) Temporal and spatial abundance of naked amoebae (Gymnamoebae) in marine benthic sectiments. J Eukaryot Microbiol 42:724-730

Capriulo GM (1990) Ecology of marine protozoa. Oxford University Press, New York

Caron DA (1983) Technique for enumeration of heterotrophic and phototrophic nanoplankton, using epifluorescence microscopy, and comparison with other procedures. Appl Environ Microbiol 46:491-498

Caron DA (1987) Grazing of attached bacteria by heterotrophic microflagellates. Microb Ecol 13:203-218

Caron DA, Davis PG, Madin LP, Sieburth JM (1982) Heterotrophic bacteria and bacterivorous protozod in oceanic macroaggregates. Science 218:795-797

Caron DA, Davis PG, Madin LP, Sieburth JM (1986) Enrichment of microbial populations in macroaggregates (marine snow) from the surface waters of the North Atlantic. J Mar Res 44:543-565

Caron DA, Davis PG, Sieburth JM (1989) Factors responsible for the differences in cultural estimates and direct microscopical counts of populations of bacterivorous nanoflagellates. Microb Ecol 18:89-104
Caron DA, Swanberg NR (1990) The ecology of planktonic sarcodines. Rev Aquat Sci 3:147-180

Cook WL, Ahearn DG, Reinhardt DJ, Reiber RJ (1974) Blooms of an algophorous amoeba associated with Anabaena in a fresh water lake. Wat Air Soil Pollut 3:71-80

Daggett PM, Sawyer TK, Nerad TA (1982) Distribution and possible interrelationship of pathogenic and nonpathogenic Acanthamoeba from aquatic environments. Microb Ecol 8:371-386

Davis PG (1976) Oceanic amoebae from the North Allantic culture, distribution, and taxonomy. MS thesis, University of Rhode Island, Kingston

Davis PG, Caron DA, Sieburth JM (1978) Oceanic amoebae from the North Atlantic: culture, distribution, and taxonomy. Trans Am Microsc Soc 96:73-88

Davoll PJ, Silver MW (1986) Marine snow aggregates: life history sequence and microbial community of abandoned larvacean houses from Monterey Bay, California. Mar Ecol Prog Ser 33:111-120

Fenchel T (1987) Ecology of protozod. Science Tech/SpringerVerlag, Madison

Fernandez MA, Crespo EP, Mallen MM, Ares MPMP, Casas MLC (1989) Marine amoebae from waters of northwest Spain, with comments on a potentially pathogenic euryhaline species. J Protozool 36:239-241

Hobbie JE (1994) The state of the microbes: a summary of a symposium honoring Lawrence Pomeroy. Microb Ecol 28: $113-116$

Hobbie JE, Daley RJ, Jasper S (1977) Use of Nuclepore filters for counting bacteria by fluorescence microscopy. Appl Environ Microbiol 33:1225-1228

Kopylov AI, Moiseyev YV (1983) Multiplication rate and production of zooflagellates in the Northeastern Black Sea. Oceanology 23:482-485

Kopylov AI, Sazhin AF (1988) Heterotrophic nano- and microplankton in the vicinity of large port cities. Oceanology $28: 472-477$

Kopylov AI, Sazhin AF (1989) Heterotrophic nanoplankton of the aerobic zone of the Black Sea. In: Vinogradov ME, Flint MV (eds) Structure and productive characteristics of plankton communities of the Black Sea. Nauka, Moscow, p 139-142 (in Russian)

Kopylov AI, Tumantseva II, Sazhin AF (1991) Heterotrophic nano- and microplankton. In: Vinogradov ME (ed) Coastal ecosystems of eastern part of the Black Sea (experiment 'Sozopol 80-86'). VNIRO, Moscow, p 127-142 (in Russian)

Kyle DE, Noblet GP (1985) Vertical distribution of potentially pathogenic free-living amoebae in freshwater lakes J Protozool 32:99-105

Kyle DE, Noblet GP (1986) Seasonal distribution of thermotolerant free-living amoebae. I. Willard's Pond. J Protozool 33:422-434

Kyle DE, Noblet GP (1987) Seasonal distribution of thermotolerant free-living amoebae. II. Lake Issaqueena. J Protozool 34:10-15

Laybourn-Parry J, Marchant HJ, Brown P (1991) The plankton of a large oligotrophic freshwater Antarctic lake. J Plankton Res 13:1137-1149

Lighthart B (1969) Planktonic and benthic bacteriovorous protozoa at eleven stations in Puget Sound and adjacent Pacific Ocean. J Fish Res Bd Can 26:299-304

Lim EE, Amaral LA, Caron DA, DeLong EF (1993) Application of rRNA-based probes for observing marine nanoplanktonic protists. Appl Environ Microbiol 59:1647-1655

Lim EL, Caron DA, DeLong EF (1996) Development and field application of a quantitative method for examining natural 
assemblages of protists using oligonucleotide probes. Appl Environ Microbiol 62:1416-1423

Makarova IV, Pishkilyi LO (1970) Some questions concerning the method of calculating phytoplankton biomass Botanichesky Zh (Leningrad) 55:1488-1494 (in Russian)

Mare MF (1942) A study of a marine benthic community with special reference to the microorganisms. J Mar Biol Ass UK 25:517-554

O'Dell WD (1979) Isolation, enumeration and identification of amoebae from Nebraska Lake. J Protozool 26:265-269

Pomeroy LR (1974) The ocean's food web, a changing paradigm. BioSci 24:499-504

Pomeroy LR. Hanson RB, McGillivary PA, Sherr BF, Kirchman D. Deibel D (1984) Microbiology and chemistry of fecal products of pelagic tunicates: rates and fates. Bull Mar Sci $35: 426-439$

Reid PC, Turley CM, Burkill PH (1991) Protozoa and their role in marine processes. Springer-Verlag, Berlin

Rogerson A (1991) On the abundance of marine naked amoebae on the surfaces of five species of macroalgae. FEMS Microbiol Ecol 85:301-312

Rogerson A (1993) Parvamoeba rugata n. g., n. sp. (Gymnamoebia, Thecamoebidae): an exceptionally small marine naked amoeba. Eur J Protistol 29:446-452

Rogerson A, Laybourn-Parry J (1992) The abundance of marine naked amoebae in the water column of the Clyde estuary. Estuar Coast Shelf Sci 34:187-196

Sawyer TK (1971) Isolation and identification of free-living marine amoebae from Upper Chesapeake Bay, Maryland. Trans Am Microsc Soc 90:44-51

Sawyer TK (1975a) Marine amoebae from surface waters of Chincoteague Bay, Virginia: one new genus and eleven new species within the families Thecamoebidae and Hyalodiscidae. Trans Am Microsc Soc 94:305-323

Sawyer TK (1975b) Marine amoebae from surface waters of Chincoteague Bay, Virginia: two new genera and nine new species within the families Mayorellidae, Flabellulidae, and Stereomyxidae. Trans Am Microsc Soc 94: $71-92$

Sawyer TK (1980) Marine amebae from clean and stressed bottom sediments of the Atlantic Ocean and Gulf of Mexico. J Protozool 27:13-32

Sawyer TK (1989) Free-living pathogenic and nonpathogenic amoebae in Maryland soils. Appl Environ Microbiol 55: $1074-1077$

Sawyer TK, Nerad TA, Lewis EJ, McLaughlin SM (1993) Acanthamoeba stevensoni n. sp. (Protozoa: Amoebida) from sewage-contaminated shellfish beds in Raritan Bay, New York. J Eukaryot Microbiol 40:742-746

Responsible Subject Editor: T. Fenchel, Helsingør, Denmark
Sawyer TK, Visvesvara GS, Harke BA (1977) Pathogenic amoebas from brackish and ocean sediments, with a description of Acanthamoeba hatchetti, n. sp. Science 196:1324-1325

Schaeffer AA (1926) Taxonomy of the amebas with description of 39 new marine and freshwater species. Carnegie Institute, Washington, DC

Senichkina LG (1986a) Calculation of cell volumes for species of the genus Exuviella Cienk. Hydrobiol Zh 22:92-94 (in Russian)

Senıchkina LG (1986b) Diatom algal cell volume calculations using cell dimensions. Hydrobiol Zh 22:56-59 (in Russian)

Sherr EB, Caron DA, Sherr BF (1993) Staining of heterotrophic protists for visualization via epifluorescence microscopy. In: Kemp P, Cole J, Sherr B, Sherr E (eds) Handbook of methods in aquatic microbial ecology. Lewis Publishers, Boca Raton, p 213-227

Sherr EB, Sherr BF (1994) Bacterivory and herbivory: key roles of phagotrophic protists in pelagic food webs. Microb Ecol 28:223-235

Sieburth JM et al. (1976) Dissolved organic matter and heterotrophic microneuston in the surface microlayers of the North Atlantic. Science 194:1415-1418

Sims G, Rogerson A, Aitken R (1994) Identification and taxonomy of marine amoebae using the small-subunit $18 \mathrm{~S}$ ribosomal RNA gene. J Eukaryot Microbiol 42(S):1A

Singh BN (1946) A method of estimating the numbers of soil protozoa, especially amoebae, based on their differential feeding on bacteria. Ann Appl Biol 33:112-119

Stoecker DK, Gifford DJ, Putt M (1994) Preservation of marine planktonic ciliates: losses and cell shrinkage during fixation. Mar Ecol Prog Ser 110:293-299

Valkanov A (1970) Beitrag zur Kenntnis der Protozoen des Schwarzen Meeres. Zool Anz 184:241-290

Verity PG, Robertson CY, Tronzo CR, Andrews MG, Nelson JR, Sieracki ME (1992) Relationships between cell volume and the carbon and nitrogen content of marine photosynthetic nanoplankton. Limnol Oceanogr 37:1434-1446

Vors $N$ (1993a) Heterotrophic amoebae, flagellates and heliozod from Arctic marine waters (North West Territories, Canada and West Greenland). Polar Biol 13:113-126

Vørs $N$ (1993b) Marine heterotrophic amoebae, flagellates and heliozoa from Belize (Central America) and Tenerife (Canary Islands), with descriptions of new species, Luffisphaera bulbochaete n. sp., L. longihastis n. sp., L. turriformis n. sp. and Paulinella intermedia n. sp. J Eukaryot Microbiol 40:272-287

Zubkov MV, Sazhin AF. Flint MV (1992) The microplankton organisms at the oxic-anoxic interface in the pelagial of the Black Sea. FEMS Microbiol Ecol 101:245-250

Manuscript first received: August 2, 1995

Revised version accepted: June 13, 1996 